DOI

\author{
๑ В. Ф. Нагорна, А. А. Гриценко, Т. Я. Москаленко \\ Одесъкий національний медичний університет
}

\title{
КОНТРАВЕРСІЙНІ ПОЗИЦІї В ДІАГНОСТИЦІ БАКВАГІНОЗУ У ВАГІТНИХ
}

КОНТРАВЕРСІЙНІ ПОЗИЦІЇ В ДІАГНОСТИЦІ БАКВАГІНОЗУ У ВАГІТНИХ. АВТорамИ на підставі обстеження 60 вагітних із баквагінозом наведені значні розбіжності результатів різних діагностичних методів. Найбільш достовірним визнано вимірювання рН піхвового вмісту та виявлення збудників Gardherella vaginalis, Atopobium vaginalis за допомогою методів ДНК-технологій.

КОНТРАВЕРСИОННЫЕ ПОЗИЦИИ В ДИАГНОСТИКЕ БАКВАГИНОЗА У БЕРЕМЕННЫХ. ОбсЛЕДОВано 60 беременНЫХ с баквагинозом. Показаны существенные расхождения в результатах разных методов диагностики. Наиболее достоверными названы рН-метрия влагалищного содержимого и идентификация возбудителей Gardherella vag., Atopobium vag. с помощью методов ДНК-технологий.

CONTROVERSIAL POSITIONS IN DIAGNOSTIC OF BACTERIAL VAGINOSIS DURING PREGNANCY. The study involved 60 pregnant women with bacterial vaginosis, showing significant differences in the results of various diagnostic methods. It was named the most reliable $\mathrm{pH}$ monitoring vaginalis content and identification of the causative agent Gardherella vaginalis, Atopobium vaginalis via DNA technology methods.

Ключові слова: вагітність, баквагіноз, діагностика.

Ключевые слова: беременность, баквагиноз, диагностика.

Key words: pregnancy, bacterial vaginosis, diagnostic.

ВСТУП. Багаторічні дискусії навколо визначення суті баквагінозу, його безпечності або небезпечності, особливо під час вагітності, методів діагностики, обов'язковості чи необов'язковості лікування знайшли конкретні відповіді, але не на всі позиції цієї проблеми. 3 чотирьох типів стану піхвової мікробіоти (нормальний, проміжковий, дисбактеріоз, аеробний вагініт), що відповідають критеріям ВООЗ, якими користуються вітчизняні лікарі, баквагіноз відносять до стану піхвового дисбактеріозу, який може бути причиною інфікування матері та плода, тому жінка потребує лікування. Найбільші труднощі, а тому й помилки, пов'язані з діагностикою баквагінозу. По суті, стан дисбіозу являє собою різке превалювання анаеробної з різким зниженням або відсутністю захисної лактобацилярної фрлори $(1,2)$. Діагностика баквагінозу складається з двох підходів: клінічного та параклінічних, тобто лабораторних. Жоден із цих методів не є абсолютно достовірним. Основний метод клінічної діагностики - метод Амселя, що визначає типові скарги (патологічні виділення з піхви, гомогенні з неприємним запахом гнилої риби, позитивний амінний тест $310 \%$ розчином КОН, «ключові клітини» при мікроскопії піхвового мазка, збільшення рН піхвового вмісту більше 4,5). 3 урахуванням того, що амінним тестом і вимірюванням рН нехтують, тест дійсно перетворюється на клінічний (скарги). Але останні спостерігаються далеко не у всіх хворих. «Ключові» клітини мають діагностичну інформативність тільки в тому випадку, коли їх вміст у препараті досягає більше 20 \% (3, 4), для лікаря-лаборанта їх ідентифрікація досить утруднена.

Лабораторний метод Ньюджента, що ідентифрікує 3 бактеріальні морфотипи: великі Гр +палички (лактобацили), невеликі Гр - та Гр варіабельні коки й кокобацили (Gardherella) і Гр- та Гр варіабельні вигнуті палички (Mobiluncus), потім оцінює їх кількість у балах, страждає на суб'єктивність, дуже затратний за часом, напруженням лікаря-лаборанта. Метод Айсон-Хея, що визначає 5 типів мікробіотики, не знайшов застосування. Він не зіставляється 3 клінічним методом Амселя (3). Культуральний метод для діагностики баквагінозу не використовується. Методи основані на критеріях ВООЗ [1] - це цитологічні методи, де підраховують кількість лейкоцитів (їх мало або вони відсутні) та ідентифрікують мікрофрлору (різке зниження лактобацил, змішана фрлора) - ненадійні, бо кількість лейкоцитів при нормоцинозі та проміжковому типі біоценозу теж зовсім низька і залежить від долабораторних та лабораторних помилок. Виходячи 3 вищезазначеного, найбільш надійним слід вважати діагностику за методом, що ідентифрікує безпосередньо збудників баквагінозу, та слід продовжити пошук методів найбільш доступних та відповідних методам визначення збудників. При баквагінозі доведено етіологічну роль Gardherella vag. та Atopobium vag. Роль інших представників поліморфної флори, характерної для баквагінозу, (Prevotella, Porphyromonas Spp) сумнівна, не доведена в дослідженнях.

МАТЕРІАЛИ ТА МЕТОДИ. Клінічну грУпУ склали 60 вагітних жінок віком від 21 до 41 року в різних термінах вагітності. При обстеженні (якісний бактеріологічний метод) у всіх жінок були виявлені Gardherella vag. або Atopobium vag., що дало можливість ставити діагноз баквагіноз. У 22 жінок після 20 тижнів вагітності, за даними УЗД доплерометрії, діагностовано диссункцію плаценти, 33 жінки 3 приводу загрози переривання, диссункції плаценти, патології прикріплення плаценти, завмерлої вагітності були госпіталізовані. У 5 вагітних був хронічний пієлонесрит у стадії загострення. У трьох вагітність настала після застосування ДРТ. У 58 (96,6 \%) вагітних були ознаки дисфункції кишечника. Клінічний аналіз скарг хворих на баквагіноз показав наступне: 
скарги були різноманітними, але констатували їх тільки 56,6 \% (34) вагітних. Серед вагітних у $35 \%$ (21) були патологічні виділення з неприємним запахом, відчуття дискомсорту в ділянці зовнішніх статевих органів, піхви та уретри: печії - у 16,6 \% (10), порушення сечовипускання - 8,4 \% (5). При гінекологічному обстеженні у 36,6 \% (34) вагітних були констатовані значні виділення з піхви, у 26,6 (16) - у вигляді сірих з неприємним запахом слідів на дзеркалі. Ознак запалення на слизових оболонках не знайдено. В роботі використані такі методи дослідження: загальноклінічний (опитування, огляд, фрізикальне, гінекологічне обстеження); цитологічний (піхвовий мазок за стандартною схемою дослідження); метод із використанням ДНК-технологій - метод мультиплексної плР у реальному часі. Застосований метод дозволяє ідентифікувати ті мікроорганізми, що не тільки можуть бути наявними в піхві, а етіологічну роль яких у виникненні іноекції піхви доведено. Метод дозволяє визначити кількісний вміст бактерій взагалі, окремо лактобактерій, трьох видів умовно-патогенних мікоплазм (M.hominis parvum, urealiticym), збудників баквагінозу - анаеробних мікробів (Gardherella vag., Atopobium vag.), групи аеробних мікробів (Enterobac, Staph spp, Strept. spp) та представників групи NCMT (N. Gonorrhoeae, Chl., trach., Mycopl., Gen., Trich. vag. ) - ІПСШ; групи грибів роду Candida (Cand. alb., glabr., krusei., trop. paraps); бактеріологічний метод дослідження піхвового вмісту; визначення рН піхвового вмісту за допомогою тест-смужок.

РЕЗУЛЬТАТИ ДОСЛІДЖЕННЯ ТА ЇХ ОБГОВОРЕНня. Проаналізовані дані отриманих бактеріологічних показників. Збудником баквагінозу у 3,3 \% (2) випадках виявлений Atopobium vag., у 96,6 \% (58) - Gardherella vag., у 28,3 \% (17) - поєднана фрлора Gardherella vag. та Atopobium vag., у 11,6 \% (7) - Mobiluncus, Corinebact. разом із Gardherella vag. та Atopobium vag. Проведено аналіз співвідношення концентрації збудників та значення pH піхвового вмісту. Констатовано: при рН 4,0 у жодної жінки не було ідентифріковано збудників баквагінозу; при pH 4,4 - у двох (3,3 \%) виділено Atopobium vag. у незначній концентрації. При рН 4,7 концентрація Gardherella vag. відмічена від незначної $(\log 3,1)$ до діагностично вагомої (log 5,7), а Atopobium vag. виділено у 6 жінок у низьких концентраціях $(\log 0,2-1,3)$. Клінічні прояви в цій групі були у 5 (8,3 \%) жінок. Більш висока концентрація збудників зареєстрована при рH 5,0 $(\log 5,4-8,5)$ у 21 (35\%) жінки, у двох - $\log 0,4-0,7$. Найвища концентрація Gardherella vag. (Atopobium vag. у 5 з 17 жінок log 6,4-8,5) відповідала рН більше 5,5. Але саме в цій групі зареєстрована найбільша присутність умовно-патогенної фрлори (Enterobac., Strept. spp) у концентрації log 4,0-6,5. Аналіз $\mathrm{pH}$ відносно аеробної флори показав, що перевищення концентрації Enterobac. $\log$ вище $3,0(3,0-5,5)$ відповідає pH 5,0; log вище $4(4,0-5,5)-\mathrm{pH} 5,5$ та вище. Аналогічні дані отримані відносно концентрації Staph. Spp. - log > 3,3 відповідає pH 5,0, концентрація Strept. spp- log > 4,8 $(5,0-6,5)$ відповідає рH 5,5 (5,5-6,5).

Зіставлення кількості лейкоцитів у мазках піхви 3 концентрацією анаеробів показало відсутність їх співвідношення. Так, кількості лейкоцитів 0-2-4 у переважаючій більшості випадків (92 \%) відповідає аеробна фрлора log > 3,3 (3,3-6,5) і pH 5-5,5 та вища; у 8 \% жінок тій же концентрації фрлори відповідало 15-20-40 лейкоцитів. Можна погодитись із думкою авторів $[4,5,6]$, які вважають, що баквагіноз на ранніх стадіях розвитку не демонструє ознаки запалення через пригніченість нейтросрілів (їх мало, фрагоцитоз незавершений). При тривалому перебігу дисбіозу вірогідність розвитку запальної реакції слизових оболонок підвищується у зв'язку з порушенням адаптаційних можливостей $[5,6]$. Треба також наголосити, що при тривалому перебігу до анаеробної фрлори приєднується аеробна і дисбіоз перетворюється на вагініт змішаної етіології. Баквагіноз, за загальним уявленням, супроводжується значним пригніченням лактофллори, на кількісний вміст якої вказують найбільш вживані цитологічний, бактеріологічний методи та застосований у роботі метод мультиплексної ПлР у реальному часі. Ми виявили невідповідність даних цих методів за показником кількості лактобакцил. Так, низькому вмісту за методом ДНК-технологій $\log 4,35$ - 6,15 тільки у 61,1 \% спостережень відповідав низький вміст (25-30 \%) лактобактерій за іншими методами.

Таким чином, у діагностиці баквагінозу, який супроводжується у вагітних різними фрормами порушення гестації, існує цілий ряд контраверсійних розбіжностей, що відносяться до оцінки ролі скарг, невідповідності бактеріологічних даних, отриманих різними методами, ненадійності такого тесту, як підрахування кількості лейкоцитів у мазках. Найбільш надійним є метод мультиплексної плР у реальному часі ідентифікування збудників, який виявляє не тільки Gardherella vag., роль якої у виникненні дисбіозу давно доведена з застосуванням ДНК-технологій, а й Atopobium vag., вказівки на роль якої в літературі з'явились недавно. Діагностично інформативним виявився також показник рН вагінального вмісту. Нам здається, що подальше вивчення ролі цих методів діагностики має сенс для своєчасного виявлення порушення стану слизової оболонки піхви та запобігання розвитку порушень перебігу вагітності пологів, післяпологового періоду.

ВисновкИ. 1. Клінічні ознаки баквагінозу виявлені тільки у 56,6 \% вагітних із верифрікованим діагнозом.

2. Збудниками баквагінозу виявлено у 3,3\% Atopobium vag. у монокультурі, у 28,3 \% в поєднанні з Gardherella vaginalis, остання виявлена у 96,7 \% жінок.

3. Найбільш діагностично інфрормативними виявились показники $\mathrm{pH}$ піхвового секрету ( $\mathrm{pH}>4,7)$, та метод із застосуванням ДНК-технологій метод мультиплексної ПлР у реальному часі, який дозволяє ідентифікувати 16-24 збудників та їх кількісний вміст відносно загальної бактеріальної маси. Визначення рН піхвового вмісту повинно використовуватись багаторазово під час вагітності лікарем і самою жінкою.

ПЕРСПЕКТИВИ ПОДАЛЬШИХ ДОСЛІДЖЕНЬ. Застосований поєднаний метод визначення $\mathrm{pH}$ піхвового вмісту та ДНК-технологій (метод мультиплексної ПРЛ у реальному часі) є перспективним методом у своєчасній діагностиці баквагінозу з таким збудником, як Atopobium vag., а тому подальше вивчення методу може бути корисним у своєчасній діагностиці та попередженні ускладнень вагітності. 
СПИСОК ЛІТЕРАТУРИ

1. Кира Е. Ф. Клиника и диагностика бактериального вагиноза / Е. Ф. Кира // Акушерство и гинекология. - 1996. - № 2. - С. 32-35.

2. Радзинский В. Е. Акушерская агрессия / В. Е. Радзинский. - М. : Изд-во журнала Status praesens, 2012. - 672 с.

3. Шейка матки, влагалище, вульва. Физиология, патология, кольпоскопия, эстетическая коррекция : руководство для практикующих врачей / под ред. С. И. Роговской, Е. В. Липовой. - М .: Издательство журнала Status praesens, 2014. $-832 \mathrm{c}$.
4. Кира Е. Ф. Бактериальный вагиноз / Е. Ф. Кира. - М. : МИА, 2012. - 472 c.

5. Микробиом и здоровье женщины (обзор литературы) / Д. С. Янковский, В. П. Широбоков, Ю. Г. Антипкин [и др.] // Репродуктивная эндокринология. - 2015. - № 4 (24). - C. 13-28.

6. Eschenback D. A. Diagnosis and clinical manifestation of bacterial vaginosis / D. A. Eschenback, S. L. Hiller // Am. G.Obstet. Gynecol. - 2002. - 158. - P. 819-828.

Отримано 17.02.16 